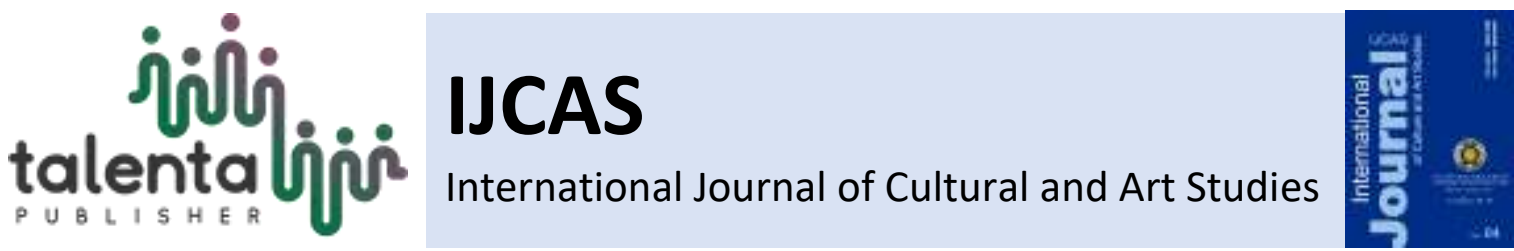

\title{
The Role of Mandarin in Indonesia's Tourism Sector
}

\author{
Dian Prasetyo Adi ${ }^{1 *}$, Ayu Rinada ${ }^{2}$ \\ Department of Chinese Language, Universitas Sebelas Maret, Surakarta, Indonesia.
}

\begin{abstract}
Indonesia is well-known for its natural beauty and cultural diversity. This becomes an extraordinary attraction for Indonesian tourism sector in which the government has also put their attention to. Tourists from others counties like to visit Indonesia. They speak in many international languages, include Mandarin. However, there are still fewer human resources who respond to it. The skill that must be possessed to prepare and improve a good image for tourists is the mastery of Mandarin. Tourism agencies who should have mastered Mandarin include travel agents, hotel employees, tour guides, and tourism practitioners. The minimum target for mastering Mandarin languages covers: simple conversations related to the work done, as well as the mastery of basic grammar and conversations. The mastery of Mandarin, as well as the understanding of the culture of Chinese tourists, is expected to provide maximum service and to create a good impression or image that improves the Indonesian tourism industry.
\end{abstract}

Keyword: Mastery of Mandarin, Language, Culture, Tourism

Received 08 March 2020 | Revised 18 March 2020 | Accepted 27 March 2020

\section{Introduction}

Indonesia is rich in its natural beauty and cultural diversity. This country is blessed for being passed by the equator and having a tropical climate. It is because people can enjoy the natural beauty of this country throughout the year without being limited or adjusting to the season. This becomes an extraordinary attraction for the world of tourism of this country.

The survey results entitled "Global Tourism Intentions Survey" by Visa [1], involving 11,620 respondents from 23 countries in the world, revealed that political stability, attractive tourism offers, and natural beauty are the main factors of foreign tourists to visit Indonesia.

Tourist attractions targeted by Chinese tourists in Indonesia are not only Bali, Jogjakarta, Lombok and Jakarta. Now, the area has already broadened, spreading throughout the country. This is because the tourism department in each region competes and tries to increase the number of tourist attractions. They continue to explore their region to be selected as a tourist destination by both exploring the potential of nature tourism and creating new tourist rides. Several examples of new tourist attractions in Yogyakarta covers Breksi Cliff, Ullen Sentalu Museum, Kali Suci, and

\footnotetext{
${ }^{*}$ Corresponding author at: Department of Chinese Language, Universitas Sebelas Maret, Surakarta, Indonesia. 
Merapi Lava Tour, not to mention tourism that utilizes nature, rafting, flower garden tour, and other attractions.

To support increased tourist visits, all parties need to consider, understand, and master things that can improve the quality of service to tourists. The mastery of foreign languages and the knowledge of various national and state stereotypes are important and cannot be abandoned, especially for the improvement of services to foreign tourists.

\section{Review of Literature}

Mandarin language includes elements of vocabulary, grammar, and phonological [2]. The pronunciation standard for learning Mandarin is Beijing pronunciation. In learning process, mastering Beijing's standard pronunciation is not easy. There are some factors that become obstacles, it can come from the teacher and students such as the perspective and habits of the learning process. But it can also come from external factors. Lack of knowledge and ability, difficulty level of pronunciation can also cause difficulties in mastering Mandarin phonology.[3]

If someone must communicate with people coming from China that speak different languages, the mastery of Mandarin that allows both to understand each other is a must. In terms of tourist services, Chinese tourists who come to Indonesia are guests who must be served, while tour agencies are servants who must serve the guests. That is why, in communicating with Chinese tourists, the tourism agencies in Indonesia must master Mandarin so they can communicate and serve guests well.

Basically, the whole process of communication with Chinese tourists requires the ability to speak and mastery of Mandarin. Foreign languages mastery holds important role in improving our tourism as it helps promotion to other countries, reservation services, accommodation services (hotels or trips), guidance services, and tourist communication with the local community.

\subsection{Promoting Tourism Abroad}

Introducing domestic tourism to foreign countries can be done in many ways. With the advancement of digital technology today, cyberspace promotion becomes the most effective one in introducing Indonesian tourism all over the world. Of course, the websites are required to use the target tourists' language. If the targets are Chinese tourists, then Mandarin is the language that must be used when promoting. Web promotion is advantageous since it can be accessed from anywhere and at any time. However, it has a slight disadvantage. Its one-way communication causes prospective tourists who want to ask questions may not be immediately served. 
For this reason, complete information and attractive design need to be included in the cyberspace promotion. The promotion must include at a minimum:

Information about the tourism destination itself that covers its location, attraction, local culture, access, hotels and facilities, other things that can be enjoyed in the area including foods and beverages along with the required costs that need always be updated.

The second way to promote Indonesian tourism is through Indonesian delegates in China, especially students who are sure to master Mandarin or international languages. This can be an effective way too, because the Indonesian delegates can introduce Indonesian tourism more comprehensibly through two-ways communication. Therefore, all the information the potential tourists are eager to know can be provided. It may include information about culture, communities and their activities, foods and beverages, and tourist destinations that can attract the people's attention to visit Indonesia as they want to know Indonesia more closely.

The third method is the conventional one. It is done by making pamphlets in Mandarin to be sent to related institutions such as travel agents and Indonesian Embassies in China, and other institutions that have links with Indonesia.

\subsection{Promoting Tourism Abroad}

Being attracted to visit Indonesia, prospective tourists will come to Indonesia in two main ways, either through or without the help of a travel agent. Whichever method chosen by those prospective Chinese tourists; they will make a reservation. The reservation activity is said to be an inseparable component from the others in the world of tourism industry. In detail, the reservation activities in hotels, airlines, and travel bureaus are similar and only have a slight difference in its practices.

The functions and duties of reservation department is not only a matter of providing a comfortable place to stay before guests or tourists come. According to Setyanto [4] the functions of the reservation department in general are:

1. Preparing place for tourists to stay (hotel rooms, in-flight seating, tours and transportation)

2. Preparing professional guides

3. Corresponding with related parties and doing archiving.

To carry out these functions, again, Mandarin mastery holds a very important role to serve Chinese tourists. It can even be said to be an absolute requirement for the reservation clerk. 


\subsection{Trip Services}

The services for Chinese tourists are provided not only when they are at the tourist sites, but from the international airport where they land in Indonesia. It covers the services carried out by the airport officers, and by the hotel or travel agent, or a tour guide who pick up the tourists in the airport. It also includes services while the tourists are on their way to or in the inn or the hotel, while they are enjoying tourist destinations, local arts, or local culture, or while they are just taking a walk to enjoy the life of the local community. The services will keep going until they return to their home country.

The services provided by the hotel to its guests are very complex, depending to the number of services and parts available at the hotel. The departments that require foreign language mastery for the communication include receptionist or front desk who communicates during the check-in and check-out, information service, and food and beverages departments. For departments such as housekeepers, bellboys and others, foreign language mastery may not be so urgent. However, it would be an extra point if those departments can also communicate with foreign languages, although the mastery is limited.

\subsection{Guidance Services}

During their trip in Indonesia, there are not only a few foreign tourists who ask for help to a tour guide. According Kurniawan [5], to be a reliable and liked by tourists, a guide must have: attractive look, broad knowledge, tons of experience, other special skills such as being a travel writer and or travel photographer. Moreover, a guide must be friendly, humorous, deft, creative, fluent and capable in communicating, honest and sincere.

Kurniawan [5] further explained the criteria as follows:

a. Attractive.

Usually, the guides who look attractive, unique, clean, and fun would be liked by tourists.

\section{b. Having broad knowledge.}

Being knowledgeable not only about the visited destination but also many other things will help to get more tourist acknowledgment. Possessing the more information about China, of course, will be an extra point for a tour guide.

\section{c. Highly experienced.}

The highly experienced tour guides have better knowledge than those who have just started. It brings a positive point for them. Another positive effect for them is the more experienced the tour guides, the more fluent their Chinese speaking will be. 


\section{d. Having special skills.}

The tour guides may have special skills, such as they can be a travel writer, and/or travel photographer. A travel writer/photographer is usually accustomed to exploring an object deeper before they are going to be published. As a result, their knowledge can be considered deeper and wider.

e. Friendly.

The friendly tour guides are mostly preferred than the unfriendly ones. This hospitality can also be adjusted to Chinese culture while having communication.

\section{f. Humorous.}

The humorous tour guides can make the journey memorable by making jokes. Tourists can laugh and be entertained by the jokes. Moreover, jokes from different countries also vary. A good mastery of Mandarin, along with good knowledge, can create amusing jokes.

\section{g. Dynamic.}

The dynamic, energetic and skillful tour guides are more preferable than those who are lethargic.

\section{h. Creative.}

The creative tour guides who deliver their story and make the journey remarkable tend to receive more praise from tourists.

\section{i. Fluent and proficient in communication}

The tour guides who tell stories using fascinating language and voice can get tourists' attention better. Fluent communication is closely related to language competence and experiences.

\section{j. Honest and sincere}

These two personalities are tour guides' assets. It can be reflected through the behavior if a guide does his job honestly and sincerely. By doing so, foreign tourists will appreciate them more.

If tour guides have a good mastery of Mandarin, which results in good communication with Chinese tourists, the 10 requirements to become professional tour guides can be accomplished. However, if Mandarin is not sufficiently mastered, it is less possible to grant the condition. 


\section{Tourism Agencies who are Required to Master Mandarin}

Tourism agencies who must master Mandarin include travel agents, hotel employees, tour guides, and local community. The minimal target in mastering Mandarin is varied according to each party.

\subsection{Travel Agents}

Travel agents must acquire advance Mandarin because they are required to explain many tour packages, tour destinations, facilities, and other things related to the tour. They include reservation and ticketing matters.

\subsection{Hotel Employees}

Hotel employees are divided into some departments:

\section{a. Front Desk/Front Office Employees}

Front Office employees are divided into two parts, which are Receptionist and Reservation. These two divisions must master Mandarin as it is used to tell check-in and check-out time, room prices, and another additional fee which should be communicated to visitors. Front Office is undeniably influential as it represents a hotel's image in front of guests.

\section{b. Housekeeping Employees}

Divisions belonged to housekeeping department, for example: room-boy, laundry, and room service, are expected to master Mandarin though it is the limited or simplest one. The housekeeping employees can use Mandarin, especially to introduce themselves, and know sentences related to their main duties.

\subsection{Tour Guides}

Mandarin mastery of tour guides for Chinese tourists is a principal requirement. If tour guides do not acquire Mandarin proficiently, they are not deserved to guide Chinese tourists. Furthermore, if tour guides have insufficient knowledge of Mandarin, they can be considered as unprofessional. Being tour guides or a leader of a tourist group can be a 'boomerang' for the tourism itself. It is because tour guides are like funnels. If they perform well, tourists will share their notable journey with other people. Otherwise, they will tell bad experiences which may cause prospective tourists to cancel their plans to visit Indonesia.

\subsection{Local Community}

People in local community should master at least basic Mandarin with simple vocabularies. The mastery includes introducing themselves and greeting Chinese tourists. Moreover, if the people 
become souvenir sellers, they should understand Chinese words related to the products they sell. Malaysia and Thailand are two examples whose citizens can speak Mandarin. Some of the Chinese tourists admit that they are happy to visit those countries, as they do not really encounter many problems related to the language.

\section{$4 \quad$ Knowledge of Chinese Culture}

Culture from another country, whether it is related to the language or another aspect, should also be mastered by tour guides to understand the communication and prevent misunderstanding. The culture includes stereotype, liked and dislike things, taboo words, and another culture differs from Indonesia's. Lacking Chinese culture's knowledge can bring a negative impact, such as misunderstanding, which can lead to negative circumstances.

\section{Conclusion}

According to calculation gained by [6], the visit number of Chinese tourists who traveled to Indonesia in 2019 is about 2 million. This is considered as the highest number after Malaysian tourists. It certainly brings a positive impact on Indonesia tourism. In order to increase the visit number of foreign tourists every year, the use of Mandarin in tourism agencies, such as travel agents, hotel employees, tour guides, even local community, is inarguably needed. In addition to the mastery of Mandarin, cultural understanding is also indispensable to prevent misunderstanding during an interaction.

\section{REFERENCES}

[1] Visa Magazine, Global Tourism Intentions Survey, PT. Visa Worldwide Indonesia No. 15, 2012,.

[2] S. Xu, Putonghua Yuyin Changshi. Beijing: Yuwen Chubanshe, 1999.

[3] A. R. W. Sukarto, E. Renata, and S. Moira, "Contrastive Analysis between Chinese and Indonesian Phonology and Implementation on Conversation Class", Int. J. Cult. Art Stud., vol. 3, no. 1, pp. 1-14, Sep. 2019.

[4] A. Setyanto, Pentingnya Penguasaan Bahasa dan Budaya Asing Sebagai Pendukung Utama Sektor Pariwisata, 2006. [Online] Available: http://fib.ub.ac.id/wrpcon/uploads/Pentingnya-Penguasaan-Bahasadan-BudayaAsing-.pdf. [Accessed Mar. 1 2020]

[5] A. Kurniawan, "Travel Plus Indonesia, Panduan Menjadi Tour Leader". [Online] Available: http://www.travelplusindonesia.blogspot.com. [Accessed: Feb. 17, 2020].

[6] Databoks, " Kunjungan Turis Tiongkok ke Indonesia Turun 3,1\% pada 2019". [Online] Available: https://databoks.katadata.co.id/datapublish/2020/02/05/kunjungan-turistiongkok-ke-indonesia-turun-31-pada-2019 [Accessed: Feb. 22, 2020]. 